\title{
Perencanaan dan Pelaksanaan Pembelajaran Pendidikan Jasmani Olahraga Kesehatan
}

\author{
Muhammad Iqbal Pambudi ${ }^{1}$, M. E. Winarno ${ }^{1}$, Wasis Djoko Dwiyogo ${ }^{1}$ \\ ${ }^{1}$ Pendidikan Olahraga-Universitas Negeri Malang
}

\section{INFO ARTIKEL}

\section{Riwayat Artikel:}

Diterima: 21-12-2018

Disetujui: 26-01-2019

Kata kunci:
planning and implementation;
sports and health physical
education learning;
perencanaan dan pelaksanaan;
pembelajaran pendidikan jasmani
olahraga dan kesehatan;

\section{Alamat Korespondensi:}

Muhammad Iqbal Pambudi

Pendidikan Olahraga

Universitas Negeri Malang

Jalan Semarang 5 Malang

E-mail: pambudiiqbal28@gmail.com

\begin{abstract}
ABSTRAK
Abstract: This research was aimed to see how the Physical Education, Sports, and Health learning process in schools from the planning and learning stages of learning by using descriptive qualitative and quantitative methods. Research procedure namely (1) making a guide instrument, (2) taking data, (3) analyzing the data, and (4) hiding the research. The study on the planning aspects of all teachers of Physical Education, Sports and Health do not make learning devices from syllabus and on the aspects of effective learning implementation which in real life are not yet standard and form in the process of learning activities in accordance with the standard. Recommendation on the planning aspect by conducting academic supervision to improve performance in and follow the standards that have been applied in the process.
\end{abstract}

\begin{abstract}
Abstrak: Penelitian ini bertujuan untuk melihat bagaimana proses pembelajaran PJOK di sekolah dari tahap perencanaan pembelajaran dan pelaksanaan pembelajaran dengan mengunakan metode deskriptif kualitatif dan kuantitatif. Prosedur penelitian yaitu (1) membuat panduan instrumen, (2) pengambilan data, (3) menganalisis data, dan (4) menyimpulkan hasil penelitian. Hasil penelitian pada aspek perencanaan semua guru PJOK tidak membuat perangkat pembelajaran dari silabus dan RPP serta pada aspek pelaksanaan pembelajaran waktu efektif yang digunakan dalam pelaksanaan pelaksanaan pembelajaran masih belum standar serta bentuk dalam proses kegiatan pembelajaran belum sesuai dengan standar. Rekomendasi pada aspek perencanaan dengan melakukan supervisi akademik guna meningkatkan kinerja dalam mengembangkan perangkat pembelajaran dan pada aspek pelaksanaan guru harus mengikuti aturan standar yang telah ditentukan dalam proses pelaksanaan pembelajaran.
\end{abstract}

Peran pendidikan sangatlah penting dalam kehidupan manusia, generasi muda sekarang yang mengemban ilmu pendidikan disiapkan untuk terampil dalam dunia pendidikan dan mampu mengubah perubahan kehidupan yang lebih baik melalui pendidikan. Dalam dunia pendidikan pasti tidak asing dengan sebutan guru yang bertugas sebagai pendidik di sekolah. Sesuai dengan tujuan yang. Diperkuat penelitian oleh (Dufour, Dube, \& Granger, 2015) menyimpulkan bahwa guru berperan menyediakan layanan pendidikan sesuai dengan tujuan pendidikan sehingga dapat menggali kemampuan peserta didik dengan hasil yang baik. Selanjutnya penelitian oleh (Ohman, Redelius, \& Quennerstedt, 2015) menyimpulkan bahwa guru sebagai fasilitator dan bertanggung jawab dengan mendirikan lingkungan terbaik. Dengan adanya pendidikan harus lebih diutamakan dalam fungsi penerapannya, dalam proses pendidikan akan terjadi interaksi yang melibatkan proses guru dan peserta didik, sehingga peserta didik diharapkan membentuk karakter yang lebih unggul.

Mengenal dunia pendidikan maka tidak akan terlepas dari istilah pembelajaran yang merupakan proses kegiatan dalam pendidikan. Pembelajaran dalam dunia pendidikan merupakan proses dimana pendidik dan peserta didik berinteraksi dalam lingkungan sekolah. Diperjelas oleh (Dwiyogo \& Cholifah, 2016) mengatakan pembelajaran bentuk program yang terencana. Selanjutnya penelitian oleh (Tiessen, 2018) menyimpulkan pembelajaran adalah proses yang melibatkan interaksi antara pembelajar, pengajar, fasilitas dan lingkungan untuk medapatkan pengetahuan, keterampilan, dan sikap dalam mencapai tujuan yang baik. Dengan adanya proses pembelajaran dalam dunia pendidikan, maka tidak terlepas dari yang namanya matapelajaran PJOK di sekolah. Diperkuat penelitian oleh (Rachman, 2004) mengatakan PJOK akan selalu ada dalam dunia pendidikan karena PJOK sangatlah dibutuhkan. Hasil penelitian (Mohammed, Wang, \& Mohammed, 2015) menyimpulkan PJOK sangat diperlukan, khususnya pada SMA sebagai persyaratan ke jenjang Universitas. Hal tersebut menunjukkan bahwa mata pelajaran PJOK telah menjadi bagian penting dari keseluruhan pendidikan. 
Dalam kegiatan pembelajaran di lingkup sekolah, khususnya dalam mata pelajaran PJOK menekankan pada aspek sikap, pengetahuan, dan keterampilan. Tentunya PJOK merupakan salah satu bagian penting yang telah ditunjuk dalam kurikulum 2013 sehingga peran PJOK dalam mencapai tujuan pendidikan nasional sangatlah penting. Hasil penelitian oleh (Koc, 2017) mengatakan bahwa matapelajaran PJOK memiliki tingtak efek positif dalam kegiatan pembelajaran disekolah yang sangat berpengaruh pada perkembangan siswa. Selain itu menurut (Wang, 2017) mengatakan bahwa PJOK memiliki pengaruh yang tak tergantikan pada pembentukan karakter moral, perkembangan intelektual, estetika pencapaian dan gaya hidup sehat. Menurut (Ryan \& Poirier, 2012) menyimpulkan bahwa PJOK harus menjadi bagian yang signifikan dari kehidupan setiap orang dan lebih memahami pentingnya PJOK dalam kehidupan sehari-hari.

PJOK merupakan bagian penting dari keseluruhan proses pendidikan dengan tujuan peningkatan kinerja manusia melalui media kegiatan fisik untuk mengembangkan dan memelihara tubuh manusia. Diperkuat penelitian oleh (Dwiyogo \& Cholifah, 2016) menjelaskan PJOK menjadi sangat penting dalam hal perkembangan dan aktivitas fisik sejak masa anak-anak sampai dewasa. Sehingga dalam proses pertumbuhan, aktivitas jasmani menjadi bagian penting dan berperan dalam proses tumbuh kembangnya peserta didik. PJOK merupakan mata pelajaran penting dan wajib yang harus ada di sekolah. Selain itu hasil penelitian oleh (Ugeltha \& Meyvilliano, 2017) menunjukkan bahwa mahasiswa yang mengikuti pembelajaran matakuliah PJOK memiliki karakter yang lebih unggul dari pada mahasiswa yang tidak mengikuti pembelajaran mata kuliah PJOK. Ini menunjukkan bahwa pentingnya matapelajaran PJOK untuk peserta didik guna menjaga kebugaran jasmaninya. Pentingnya mata pelajaran PJOK tidak terlepas dari guru PJOK yang berkualitas dan profesional. Hasil penelitian (Arifin, 2017) menunjukkan peran guru PJOK ialah kualitas SDM meningkat dengan berbagai aktivitas jasmani.

Lumajang merupakan Kabupaten yang terbentuk pada tahun 1990 di Provinsi Jawa Timur dengan luas daerah 1790,90 km2, memiliki jumlah penduduk 1,035 juta penduduk pada tahun 2014 dan memiliki 21 Kecamatan. Berdasarkan data sekolah oleh Kementrian Pendidikan dan Kebudayaan yang ada di Kabupaten Lumajang khususnya pada SMA Negeri adalah 13 SMA Negeri sudah memiliki akreditasi A. Hanya 20\% sekolah SMA di Kabupaten Lumajang yang menerapkan kurikulum 2013. Tentunya ini menjadi masalah penting dalam dunia pendidikan khususnya di Kabupaten Lumajang pada sekolah SMA karena penerapan kurikulum 2013 sangat tidak maksimal dan belum menyeluruh $100 \%$.

Salah satu pusat dari kabupaten Lumajang adalah kecamatan Lumajang yang mayoritas memiliki infrasuktur pemerintahan terpusat di kecamatan Lumajang karena letaknya yang strategis. Kecamatan Lumajang memiliki luas 179 , $1 \mathrm{~km} 2$ dengan memiliki 3 SMA Negeri yang sudah terakdreditasi A dan melaksanakan pembelajaran menggunakan kurikulum 2013 diantaranya (1) SMAN 1 Lumajang, (2) SMAN 2 Lumajang, dan (3) SMAN 3 Lumajang. Kecamatan Lumajang menjadi pusat pendidikan favorit di Kabupaten Lumajang, tentunya sebagai pusat pendidikan di Kabupaten Lumajang bukan berarti menjadi tolak ukur keberhasilan dalam dunia pendidikan. Selain itu, kecamatan Lumajang memiliki keunggulan salah satunya dari segi pembangunan, seperti gedung sekolah, gedung Pendidikan, GOR Wira Bhakti Lumajang serta Alun-alun Lumajang yang terletak di pusat Kecamatan Lumajang. Selanjutnya dalam bidang pendidikan pada prestasi akademik sudah bagus dibuktikan dengan menjuarai Olimpiade Sains Nasional Bidang IPA tingkat Nasional tahun 2017, sedangkan pada prestasi non akademik masih belum terlihat. Sehingga pada prestasi non akademik menjadi salah satu masalah yang ada.

Untuk mencapai tujuan pembelajaran PJOK salah satunya dengan meningkatkan kualitas standar proses, karena standar proses menjadi bagian penting dalam dunia pendidikan untuk ketercapaian tujuan pendidikan nasional. Diperjelas penelitian oleh (Nwike \& Catherine, 2013) menyimpulkan proses pembelajaran merupakan perlakuan mengajar yang digunakan di lingkungan sekolah untuk mencapai tujuan yang diharapkan. Diperkuat oleh (Brown, Trevisan, Callahan, Harder, \& Orlich, 2010) mengatakan bahwa proses pembelajaran merupakan elemen kunci dalam bidang pendidikan untuk menentukan kualitas pendidikan. Dengan adanya pelaksanaan pembelajaran yang dilakukan dengan baik maka kualitas proses pembelajaran dalam pendidikan akan tercapai dengan baik. Selanjutnya, hasil penelitian oleh Arfianto (2013) menyimpulkan bahwa proses evaluasi pembelajaran PJOK di SMA/SMK se-Kecamatan Rembang Kabupaten Rembang tahun 2012 menunjukkan kriteria yang baik yang berpengaruh pada hasil belajar peserta didik.

Hasil penelitian oleh (Sulistiono, 2014) survei tingkat kebugaran jasmani siswa pendidikan dasar dan menengah di Jawa Barat siswa belum seluruhnya berada dalam kondisi yang baik. Hanya 11,88\% siswa SD yang memiliki kebugaran jasmani yang baik, sedangkan 42,27\% rendah, dan 45,86\% pada level sedang. Siswa SMP hanya 9,50\% siswa memiliki kebugaran jasmani baik, sedangkan 36,87\% masih memiliki tingkat kebugaran jasmani rendah dan 53,63\% memiliki kebugaran jasmani pada level sedang. Siswa SMU sebanyak 46,11\% masih memiliki tingkat kebugaran jasmani rendah, 10,56\% siswa memiliki kebugaran jasmani sesuai harapan, dan 43,33\% memiliki kebugaran jasmani pada level sedang. Dari penelitian tersebut menunjukkan kesegaran jasmani siswa di Jawa Barat masih kurang dan perlu diadakan evaluasi untuk memperbaiki kondisi yang telah ada. Tentunya proses pembelajaran menjadi bagian penting dan berpengaruh pada hasil kesegaran jasmani siswa di Jawa Barat. Selanjutnya, hasil penelitian (Rachman, 2011) mengatakan bahwa keterlaksanaan pembelajaran PJOK di DIY berada pada kategori C yang berarti hanya masuk klasifikasi sedang dengan persentase keterlaksanaan sebesar 50,5\% dan dapat dikatakan belum mencapai tujuan pendidikan yang diharapkan, tentunya ini menjadi salah satu masalah pada implementasinya. Penelitian oleh (Mukhit, 2016) mengatakan bahwa siswa yang mengikuti pembelajaran PJOK memperoleh kebugaran yang lebih baik, aktif dalam mengikuti penjelasan guru dan selalu konsentrasi dalam mengikuti pelajaran, tentunya ini juga bergantung pada pelaksanaan pembelajaran PJOK yang dilakukan secara prosedur, tentunya proses pembelajaran menjadi bagian penting untuk mencapai tujuan pendidikan yang diaharapkan. Penelitian oleh (Alaswati, 2016) pelaksanaan 
pembelajaran kurikulum 2013 PJOK di Kabupaten Kendal sudah berjalan dengan baik tentunya sangat berdampak pada hasil yang baik pada siswa. Diperkuat kembali oleh penelitian (Orlanda, 2015) mengatakan program PJOK harus mempertimbangkan tujuan, kurikulum, dan metode pengajaran untuk meningkatkan efektivitas dalam pembelajaran.

Evaluasi merupakan proses kegiatan dalam mengukur sesuatu khususnya dalam dunia pendidikan. Untuk mengetahui proses pembelajaran yang baik dapat dilakukan dengan melakukan evaluasi pada proses pembelajaran. Diperkuat penelitan oleh (Warsito \& Kartowagiran, 2013) menjelaskan bahwa evaluasi merupakan suatu proses yang dapat digunakan untuk menilai kualitas dari apa yang telah terjadi. Selain itu, menurut (Samkange, 2012) mengatakan inti dari kegiatan evaluasi adalah proses yang dihasilkan informasi dan data untuk menjadi alternatif sebagai tindakan keputusan. Hasil penelitian oleh (Wagner, Babson, \& Murray, 2011) menyimpulkan bahwa evaluasi sangat penting bagi perubahan yang kredibel dalam sistem pendidikan di seluruh negara. (Jahanian, 2012) menyimpulkan bahwa evaluasi dalam pendidikan harus memperhatikan tujuan dan prosedur dalam pembelajaran untuk mencapai tujuan pendidikan. Dengan melakukan evaluasi akan diperoleh informasi yang diinginkan dan sesuai dengan kebutuhan, bukan hanya menitikberatkan pada hasil belajar melainkan juga dengan proses pembelajaran yang berdampak pada kualitas pembelajaran. Sampai saat ini belum pernah ada evaluasi proses pembelajaran PJOK di SMA Negeri Lumajang.

\section{METODE}

Rancangan penelitian ini untuk mengetahui proses pembelajaran PJOK di SMA Negeri Lumajang dengan menggunakan penelitian deskriptif kualitatif dan kuantitatif. Peneliti menyimpulkan bahwa prosedur penelitian yang dilakukan diantaranya (1) peneliti membuat panduan instrumen penelitian, (2) peneliti melakukan pengambilan data, (3) peneliti menganalisis data yang ditemukan, (4) peneliti menarik kesimpulan dan mengambil keputusan yang tepat.

Subjek penelitian ini menggunakan penelitian kualitatif pada proses pembelajaran PJOK di SMA Negeri Lumajang sebanyak tiga SMA, diantaranya (1) SMAN 1 Lumajang, (2) SMAN 2 Lumajang, (3) SMAN 3 Lumajang. Penelitian ini dilakukan di Kabupaten Lumajang, dengan waktu penelitian mulai bulan September sampai dengan Oktober 2018.

Pada prinsipnya meneliti adalah melakukan pengukuran, maka harus ada alat ukur yang baik. Instrumen yang digunakan dalam penelitian ini diantaranya (1) dokumentasi, (2) angket, dan (3) observasi. Hasil analisis akan dikonversikan ke dalam bentuk analisis deskriptif persentase (\%) sesuai dengan kriteria Tabel 1.

Tabel 1. Klasifikasi Nilai dalam Persentase (\%)

\begin{tabular}{cll}
\hline No. & Persentase & Klasifikasi \\
\hline 1 & $80-100 \%$ & Baik Sekali \\
2 & $66-79 \%$ & Baik \\
3 & $56-65 \%$ & Cukup Baik \\
4 & $40-55 \%$ & Kurang Baik \\
5 & $<39 \%$ & Tidak Baik \\
\hline
\end{tabular}

Setelah data-data tersebut menjadi data kualitatif deskriptif, maka selanjutnya dilakukan pengeolahan data sebagai berikut, di antaranya (1) reduksi data dilakukan untuk menganalisis dengan memilih hal pokok dalam penelitian, di antaranya (1) dokumentasi, (2) observasi, dan (3) angket. Dengan demikian, hasil penelitian tersebut dapat digunakan dalam mereduksi data yang dibutuhkan yang berkaitan dalam pelaksanaan pembelajaran PJOK, (2) menyajikan data, dan (3) membentuk kesimpulan.

Hasil terjemahan observasi pada Pelaksanaan PJOK di SMA Negeri Lumajang dari hasil observasi sembilan kali pertemuan dalam pelaksanaan pembelajaran PJOK di SMA Negeri 1 Lumajang oleh observer satu dan observer dua dapat disimpulkan, di antaranya (1) kegiatan pendahuluan dengan jumlah total 135 menit, rata-rata dalam kegiatan pendahuluan 15 menit dan persentase dalam pelaksanaan pembelajaran 50\% yang berarti dalam kategori kurang baik, (2) kegiatan inti dengan jumlah total 708 menit, rata-rata dalam kegiatan pendahuluan 79 menit dan persentase dalam pelaksanaan pembelajaran $37 \%$ yang berarti dalam kategori tidak baik, (3) kegiatan penutup dengan jumlah total 139 menit, rata-rata dalam kegiatan pendahuluan 15 menit dan persentase dalam pelaksanaan pembelajaran 51\% yang berarti dalam kategori kurang baik, dan (4) waktu efektif yang diguanakan dalam pembelajaran dengan jumlah total 838 menit, rata-rata dalam kegiatan pendahuluan 93 menit dan persentase dalam pelaksanaan pembelajaran $34 \%$ yang berarti dalam kategori tidak baik.

Untuk di SMA Negeri 2 Lumajang oleh observer satu dan observer dua dapat disimpulkan (1) kegiatan pendahuluan dengan jumlah total 145 menit, rata-rata dalam kegiatan pendahuluan 16 menit dan persentase dalam pelaksanaan pembelajaran $54 \%$ yang berarti dalam kategori kurang baik, (2) kegiatan inti dengan jumlah total 780 menit, rata-rata dalam kegiatan pendahuluan 87 menit dan persentase dalam pelaksanaan pembelajaran $41 \%$ yang berarti dalam kategori kurang baik, (3) kegiatan penutup dengan jumlah total 52 menit, rata-rata dalam kegiatan pendahuluan 6 menit dan persentase dalam pelaksanaan pembelajaran 19\% yang berarti dalam kategori tidak baik, dan (4) waktu efektif yang digunakan dalam pembelajaran dengan jumlah total 679 menit, rata-rata dalam kegiatan pendahuluan 75 menit dan persentase dalam pelaksanaan pembelajaran $28 \%$ yang berarti dalam kategori tidak baik. Sedangkan di SMA Negeri 3 Lumajang dapat disimpulkan diantaranya (1) kegiatan pendahuluan dengan jumlah total 187 menit, rata-rata dalam kegiatan pendahuluan 21 menit dan 
persentase dalam pelaksanaan pembelajaran $69 \%$ yang berarti dalam kategori baik, (2) kegiatan inti dengan jumlah total 899 menit, rata-rata dalam kegiatan pendahuluan 100 menit dan persentase dalam pelaksanaan pembelajaran $48 \%$ yang berarti dalam kategori kurang baik, (3) kegiatan penutup dengan jumlah total 58 menit, rata-rata dalam kegiatan pendahuluan 6 menit dan persentase dalam pelaksanaan pembelajaran $21 \%$ yang berarti dalam kategori tidak baik, dan (4) waktu efektif yang digunakan dalam pembelajaran dengan jumlah total 909 menit, rata-rata dalam kegiatan pendahuluan 101 menit dan persentase dalam pelaksanaan pembelajaran $37 \%$ yang berarti dalam kategori tidak baik.

HASIL

Analisis Data Perencanaan Deskriptif Kualitatif

Tabel 2. Analisis Data Perencanaan PJOK di SMA Negeri Lumajang

\begin{tabular}{|c|c|c|c|c|}
\hline \multirow{2}{*}{\multicolumn{2}{|c|}{\begin{tabular}{cl} 
Aspek & \multicolumn{1}{c}{ Aktivitas } \\
Perencanaan & $\begin{array}{l}\text { Studi Dokumen Silabus dan } \\
\text { RPP }\end{array}$
\end{tabular}}} & Sekolah & Guru & Keterangan \\
\hline \multirow[t]{9}{*}{ Perencanaan } & & & Guru A & $\begin{array}{l}\text { Tidak ditemukan silabus dan RPP serta rubrik penilaian karena tidak } \\
\text { terbukti adanya dokumen. }\end{array}$ \\
\hline & & & Guru B & $\begin{array}{l}\text { Tidak ditemukan silabus dan RPP serta rubrik penilaian karena tidak } \\
\text { terbukti adanya dokumen. }\end{array}$ \\
\hline & & & Guru C & $\begin{array}{l}\text { Tidak ditemukan silabus dan RPP serta rubrik penilaian karena tidak } \\
\text { terbukti adanya dokumen. }\end{array}$ \\
\hline & & $\begin{array}{l}\text { SMA N } 2 \\
\text { Lumajang }\end{array}$ & Guru A & $\begin{array}{l}\text { Tidak ditemukan silabus dan RPP serta rubrik penilaian karena tidak } \\
\text { terbukti adanya dokumen. }\end{array}$ \\
\hline & & & Guru B & $\begin{array}{l}\text { Tidak ditemukan silabus dan RPP serta rubrik penilaian karena tidak } \\
\text { terbukti adanya dokumen. }\end{array}$ \\
\hline & & & Guru C & $\begin{array}{l}\text { Tidak ditemukan silabus dan RPP serta rubrik penilaian karena tidak } \\
\text { terbukti adanya dokumen. }\end{array}$ \\
\hline & & $\begin{array}{l}\text { SMA N } 3 \\
\text { Lumajang }\end{array}$ & Guru A & $\begin{array}{l}\text { Tidak ditemukan silabus dan RPP serta rubrik penilaian karena tidak } \\
\text { terbukti adanya dokumen. }\end{array}$ \\
\hline & & & Guru B & $\begin{array}{l}\text { Tidak ditemukan silabus dan RPP serta rubrik penilaian karena tidak } \\
\text { terbukti adanya dokumen. }\end{array}$ \\
\hline & & & Guru C & $\begin{array}{l}\text { Tidak ditemukan silabus dan RPP serta rubrik penilaian karena tidak } \\
\text { terbukti adanya dokumen. }\end{array}$ \\
\hline Kesimpulan & & & & $\begin{array}{l}\text { Perencanaan pembelajaran di SMA Negeri Lumajang adalah guru } \\
\text { tidak membuat silabus dan RPP serta rubrik penilaian karena tidak } \\
\text { terbukti ada dokumen tersebut }\end{array}$ \\
\hline
\end{tabular}

Analisis Data Hasil Pelaksanaan Pembelajaran Deskriptif Kuantitatif

Tabel 3. Data Hasil Keseluruhan Deskriptif Kuantitatif PJOK di SMA Negeri Lumajang

\begin{tabular}{|c|c|c|c|c|c|c|c|c|c|c|}
\hline \multirow{2}{*}{ Aspek } & \multirow{2}{*}{ Aktivitas } & \multirow{2}{*}{$\begin{array}{l}\text { Skor } \\
\text { Maks }\end{array}$} & \multicolumn{3}{|c|}{ Skor Hasil } & \multirow{2}{*}{-Jumlah } & \multirow{2}{*}{ Rerata } & \multirow{2}{*}{$\%$} & \multirow{2}{*}{$\begin{array}{c}\text { Jumlah } \\
\text { Total Maks }\end{array}$} & \multirow{2}{*}{$\begin{array}{c}\% \\
\text { Total }\end{array}$} \\
\hline & & & SMAN 1 & SMAN 2 & SMAN 3 & & & & & \\
\hline \multirow{4}{*}{ Pelaksanaan } & $\begin{array}{l}\text { Observasi } \\
\text { Kegiatan } \\
\text { Awal }\end{array}$ & $15 \mathrm{~m}$ & $8 \mathrm{~m}$ & $8 \mathrm{~m}$ & $10 \mathrm{~m}$ & $26 \mathrm{~m}$ & $9 \mathrm{~m}$ & $58 \%$ & $45 \mathrm{~m}$ & \multirow{4}{*}{$43 \%$} \\
\hline & $\begin{array}{l}\text { Observasi } \\
\text { Kegiatan } \\
\text { Inti }\end{array}$ & $105 \mathrm{~m}$ & $39 \mathrm{~m}$ & $43 \mathrm{~m}$ & $50 \mathrm{~m}$ & $133 \mathrm{~m}$ & $44 \mathrm{~m}$ & $42 \%$ & $315 \mathrm{~m}$ & \\
\hline & $\begin{array}{l}\text { Observasi } \\
\text { Kegiatan } \\
\text { Penutup }\end{array}$ & $15 \mathrm{~m}$ & $8 \mathrm{~m}$ & $3 \mathrm{~m}$ & $3 \mathrm{~m}$ & $14 \mathrm{~m}$ & $5 \mathrm{~m}$ & $31 \%$ & $45 \mathrm{~m}$ & \\
\hline & $\begin{array}{l}\text { Waktu } \\
\text { Efektif }\end{array}$ & $135 \mathrm{~m}$ & $55 \mathrm{~m}$ & $54 \mathrm{~m}$ & $64 \mathrm{~m}$ & $172 \mathrm{~m}$ & $57 \mathrm{~m}$ & $43 \%$ & $405 \mathrm{~m}$ & \\
\hline Jumlah & & $270 \mathrm{~m}$ & $109 \mathrm{~m}$ & $109 \mathrm{~m}$ & $127 \mathrm{~m}$ & $345 \mathrm{~m}$ & \multirow{3}{*}{$\begin{array}{c}115 \mathrm{~m} \\
19 \mathrm{~m}\end{array}$} & & \multirow{3}{*}{$810 \mathrm{~m}$} & \\
\hline Rerata & & $68 \mathrm{~m}$ & $27 \mathrm{~m}$ & $27 \mathrm{~m}$ & $32 \mathrm{~m}$ & $29 \mathrm{~m}$ & & & & \\
\hline Persentase & & $100 \%$ & $40 \%$ & $40 \%$ & $47 \%$ & $43 \%$ & & & & \\
\hline
\end{tabular}

\section{PEMBAHASAN}

Pada aspek perencanaan pembelajaran di SMA Negeri Lumajang khususnya pada SMA Negeri 1 Lumajang, SMA Negeri 2 Lumajang, dan SMA Negeri 3 Lumajang berdasarkan hasil dokumentasi dari guru PJOK pada masing-masing sekolah untuk silabus dan RPP ketika peneliti meminta file berupa hardcopy maupun softcopy sebelum melakukan penelitian dan masuk pada penelitian tidak ditemukan dan tidak ada bukti dokumen perangkat tersebut serta banyak yang memberikan alasan-alasan, seperti (1) merevisi rencana pelaksanaan pembelajaran dari MGMP Olahraga Kabupaten Lumajang, (2) masih ada instrumen 
penilaian yang belum sesuai, (3) nanti sepulang sekolah, (4) kuota internet habis, (5) tidak punya laptop, (6) laptop masih dibetulkan, dan (7) masih sibuk mengurus Pekan Olahraga Pelajar Kabupaten (POPKAB). Tentunya pembelajaran yang kurang akan kesiapan sebelum mengajar akan berdampak pada pelaksanaan pembelajaran serta tidak sesuai dengan tujuan yang diharapkan sehingga proses pembelajaran menjadi tidak terarah. Jadi, dapat disimpulkan bahwa guru PJOK pada SMA Negeri 1, SMA Negeri 2, dan SMA Negeri 3 Lumajang belum merancang silabus dan RPP sehingga kegiatan pembelajaran kurang sistematis dan berdampak buruk.

Hasil temuan di atas juga serupa dengan (Suryapermana, 2017) mengatakan bahwa perencanaan pembelajaran yang tidak dilakukan secara sistematis akan berdampak kegagalan dalam proses kegiatan pembelajaran serta menjadi malapetaka dalam dunia pendidikan. Selain itu, penelitian oleh (Dimyati, 2014) mengatakan bahwa kompetensi pedagogik guru PJOK SMP di Kota Yogyakarta dalam mengintegrasikan pendidikan karakter yang terwujud dalam penyusunan Rencana Pelaksanaan Pembelajaran masih rendah. Tentunya perencanaan pembelajaran menjadi bagian penting sebelum kegiatan pembelajaran dilaksanakan. Perencanaan pembelajaran teroganisir dan sistematis akan berdampak baik pada pembelajaran serta mencapai tujuan pembelajaran yang baik. Jadi, dengan pembuatan perencanaan pembelajaran yag tersusun secara sistematis dengan menetapkan tujuan akan berdampak baik pada hasil kegiatan pembelajaran yang juga dapat mencapai tujuan pendidikan nasional.

Solusi yang sesuai dalam perencanaan pembelajaran tersebut adalah guru harus membuat perangkat pembelajaran sebelum melaksanakan pembelajaran dengan melalui supervisi akademik. Melalui supervisi akademik guru dapat meningkatkan kualitas menyusun silabus dan RPP. Hasil penelitian oleh (Jones, Happé, Gilbert, Burnett, \&Viding, 2017) tentang Upaya Peningkatan Kompetensi Guru dalam Menyusun Silabus dan RPP Melalui Supervisi Akademik yang Berkelanjutan di SD Gambiran, maka dapat disimpulkan bahwa melalui supervisi akademik yang dilaksanakan secara berkelanjutan ini dapat meningkatkan kompetensi guru dalam menyusun silabus dan RPP di Sekolah Dasar Gambiran UPT Pengelola TK/SD Wilayah Timur. Hal itu dapat dibuktikan dari hasil guru dalam menyusun silabus dan RPP pada siklus I menunjukkan angka sebesar $55 \%$, dan pada siklus II sebesar 85\% sehingga terdapat peningkatan ketuntasan dari siklus pertama ke siklus kedua. Diperkuat oleh (Erfan, Supriyanto, Burhanuddin, 2016) tentang Penerapan Supervisi Klinis Pada Guru Penjaskes dapat disimpulkan bahwa penerapan supervisi klinis memberikan solusi terhadap permasalahan pembelajaran yang dilakukan guru penjaskes dalam pengelolaan kelas dan metode ceramah, solusinya yaitu (1) pengaturan tempat duduk kelompok harus lebih diperhatikan, (2) lebih banyak bertanya sehingga siswa termotivasi untuk fokus mendengarkan, (3) jangan terlalu cepat dalam menyampaikan konsep pembelajaran dan dalam menanamkan konsep tersebut perlu melakukan pengulangan, dan (4) memberikan kesempatan kepada siswa bertanya, serta memotivasi mereka dalam mengerjakan tugas.

Berdasarkan hasil sembilan kali observasi pada aspek pelaksanaan pembelajaran di SMA Negeri Lumajang, khususnya di SMA Negeri 1, SMA Negeri 2, dan SMA Negeri 3 pelaksanaan pembelajaran pada guru PJOK masing-masing sekolah sebagai berikut. Pertama, SMA Negeri 1 Lumajang diantaranya (a) waktu efektif yang digunakan dalam pembelajaran adalah 47 menit, (b) kegiatan pendahuluan rata-rata adalah 8 menit, (c) untuk kegiatan inti rata-rata adalah 39 menit, (d) untuk kegiatan penutup rata-rata adalah 8 menit. Kedua, SMA Negeri 2 Lumajang diantaranya (a) waktu efektif yang digunakan dalam pembelajaran adalah 38 menit, (b) kegiatan pendahuluan rata-rata adalah 8 menit, (c) untuk kegiatan inti rata-rata adalah 43 menit, (d) untuk kegiatan penutup rata-rata adalah 3 menit. Ketiga, SMA Negeri 3 Lumajang, di antaranya (a) waktu efektif yang digunakan dalam pembelajaran adalah 51 menit, (b) kegiatan pendahuluan rata-rata adalah 10 menit, (c) untuk kegiatan inti rata-rata adalah 50 menit, (d) untuk kegiatan penutup rata-rata adalah 3 menit. Secara keseluruhan pelaksanaan pembelajaran di SMA Negeri Lumajang diantaranya (1) waktu efektif yang digunakan dalam pembelajaran adalah 45 menit, (2) kegiatan pendahuluan rata-rata adalah 9 menit, (3) untuk kegiatan inti rata-rata adalah 44 menit, (4) untuk kegiatan penutup rata-rata adalah 5 menit. Tentunya pelaksanaan pembelajaran PJOK di SMA Negeri Lumajang jauh dari standar. Alokasi waktu pembelajaran perjam untuk SMA/MA adalah 45 menit, waktu pembelajaran tiap pertemuan 3 x 45 menit adalah 135 menit sehingga masalah ini menjadi bagian penting yang harus dibenahi khusunya dalam waktu pembelajaran efektif harus lebih ditingkatkan dalam pengunaannya.

Selain itu, hasil observasi pada pelaksanaan pembelajaran PJOK proses pembelajaran terdapat kendala yaitu terbuangnya waktu untuk mengganti pakaian olahraga, perjalanan menuju lapangan atau persewaan tempat pemandian, seperti kolam renang selokambang cukup menyita waktu banyak dalam pembelajaran, hal itu juga menyebabkan kegiatan pembelajaran menjadi berkurang dan tidak maksimal dalam penggunaan waktunya. Selain itu, hasil temuan pada saat kegiatan pendahuluan guru tidak melakukan persiapan untuk berdoa, pada kegiatan inti rata-rata pembelajaran saintifik diantaranya (1) mengamati, (2) mencoba, dan (3) mengasoisasi, serta pada kegiatan penutup rata-rata- hanya melakukan evaluasi proses pembelajaran saja. Hasil penelitian oleh (Suyatmini, 2017) menyimpulkan bahwa pelaksanaan kegiatan pembelajaran diorganisasikan menjadi kegiatan pendahuluan diantaranya (1) berdoa, (2) presensi kehadiran siswa, (3) stretching atau dikenal dengan pemanasan.

Solusi yang sesuai dalam pelaksanaan pembelajaran tersebut adalah guru harus mengikuti standar yang telah ditetapkan mulai dari kegiatan pendahuluan, kegiatan inti, dan kegiatan penutup, tentunya guru harus mengatur waktu masingmasing kegiatan dan membuat rencana pelaksanaan pembelajaran agar pembelajaran dapat terukur dengan baik dan pembelajaran berjalan dengan efektif. Hasil penelitian oleh (Rohmawati, 2015) menyimpulkan bahwa peran guru terhadap efektivitas pembelajaran di TK Miftahul Huda terjadi karena adanya kesiapan guru dalam merencanakan pembelajaran yang sesuai dengan tujuan yang ingin dicapai, sikap dan memberikan dorongan motivasi serta pemberian nilai yang jujur terhadap 
hasil yang diperoleh anak. Selain itu, hasil penelitian oleh (Nelly, 2016) menyimpulkan bahwa guru sebagai promotor dalam kegiatan belajar mengajar harus mampu mempertimbangkan waktu pembelajaran. Diperkuat penelitian oleh (Pill, 2016) menyimpulkan bahwa guru PJOK harus melihat peran sebagai desainer dalam kegiatan pembelajaran.

Dari penelitian tersebut dapat disimpulkan bahwa dengan melakukan penerapan supervisi akademik dalam kegiatan pembelajaran dapat memberikan solusi yang ada khususnya dalam pelaksanaan pembelajaran khususnya pada guru PJOK pada SMA Negeri 1 Lumajang, SMA Negeri 2 Lumajang, dan SMA Negeri 3 Lumajang dapat memberikan solusi dalam pelaksanaan pembelajaran di sekolah serta dapat meningkatkan kualitas guru dalam upaya meningkatkan efektivitas pembelajaran.

\section{SIMPULAN}

Pada aspek perencanaan pembelajaran semua guru belum membuat silabus dan RPP serta dikarenakan peneliti tidak menemukan dokumen terkait. Pada aspek pelaksanaan pembelajaran waktu efektif yang digunakan pada saat melaksanakan pembelajaran masih jauh dari standar yang telah ditetapkan. Dimulai dari kegiatan pendahuluan masih belum mencakup semua hanya melakukan presensi daftar hadir siswa dan memberikan contoh pemanasan, untuk kegiatan inti belum mencakup semua dari pembelajaran saintifik hanya melakukan mengamati, mencoba, dan mengasosiasi untuk kegiatan penutup guru hanya memberikan evaluasi pembelajaran.

Saran pada aspek perencanaan pembelajaran seharusnya guru membuat perencanaan silabus dan RPP yang sesuai dengan karakter siswa serta sekolah. Selain itu, pihak sekolah juga harus membantu dalam pengadaan pembuatan perencanaan pembelajaran yang nantinya dapat mencapai tujuan yang diharapkan serta memantau guru dalam mengumpulkan perencanaan pada awal semester sebelum kegiatan pembelajaran dimulai, untuk pada aspek pelaksnaan pembelajaran seharusnya guru harus mengacu dengan standar yang telah ditentukan mulai dari kegiatan awal, kegiatan inti, dan kegiatan penutup. Selain itu, pembelajaran harus dirancang dan dilakukan seefektif mungkin sesuai dengan waktu yang telah ditetapkan serta pihak sekolah memantau guru dalam melaksanakan pembelajaran agar pembelajaran dapat digunakan secara maksimal.

\section{DAFTAR RUJUKAN}

Alaswati, S., Rahayu, S., \& Rustiana, E. R. (2016). Evaluasi Pelaksanaan Pembelajaran Kurikulum 2013 PJOK. Journal of Physical Education and Sports, 5(2), 111-119.

Arifin, S. (2017). Peran Guru Pendidikan Jasmani Dalam Pembentukan Pendidikan Karakter Peserta Didik. Jurnal Multilateral, 16(1), 78-92.

Dimyati. (2014). Sports Education Teachers' Ability in Writing Character Vision. Jurnal Pendidikan Karakter, 4(3), $245-251$.

Dufour, F., Dube, F., \& Granger, N. (2015). Assessment of Coating Quality in Cathodic Protection and Coating Systems. Journal of Educational Research, 3(6), 07-712. https://doi.org/10.12691/education-3-6-7

Dwiyogo, W. D., \& Cholifah, P. S. (2016). Continuing Professional Development for Physical Education Teacher in Elementary School through Blended Learning. International Conference on Education, (14), 948-955.

Erfan., Supriyanto, A., \& Burhanuddin. (2016). Penerapan Supervisi Klinis pada Guru Penjaskes. Jurnal Pendidikan: Teori, Penelitian, dan Pengembangan, 1(12), 2272-2276.

Jahanian, R. (2012). Educational Evaluation: Functions and Applications in Educational Contexts. International Journal of Academic Research in Economics and Management Sciences, 1(2), 2226-3624.

Jones, A. P., Happé, F. G. E., Gilbert, F., Burnett, S., \&Viding, E. (2010). Feeling, caring, knowing: different types of empathy deficit in boys with psychopathic tendencies and autism spectrum disorder. Journal of Personality and Social Psychology, 1(1), 1188-1197. https://doi.org/10.1111/j.1469-7610.2010.02280.x

Koc, Y. (2017). The Effect of "Physical Education and Sport Culture" Course on the Attitudes of Preservice Classroom Teachers towards Physical Education and Sports. International Journal of Higher Education, 6(4), 200. https://doi.org/10.5430/ijhe.v6n4p200

Mohammed, A. S., Wang, X. Z., \& Mohammed, Y. S. (2015). The Current Status of Physical Education Curriculum at high schools In Sudan. Journal of Scientific and Research Publications, 5(3), 1-7.

Mukhit, A. (2016). Journal of Physical Education, Health and Sport. Journal of Physical Education, Sport, Health and Recreation, 1(1), 44-49.

Nelly. (2016). Efektivitas Jam Belajar Mengajar Matematika dan Bahasa bagi Murid PAUD. Jurnal Pendidikan, 1(2), 66-83.

Nwike, M. C., \& Catherine, O. (2013). Effects of Use of Instructional Materials on Students Cognitive Achievement in Agricultural Science. Journal of Educational and Social Research, 3(5), 103-108. https://doi.org/10.5901/jesr.2013.v3n5p103

Ohman, M., Redelius, K., \& Quennerstedt, M. (2015). Communicating Aims and Learning Goals in Physical Education: Part of a Subject for Learning? Sport, Education and Society, 20(5), 641-655. https://doi.org/10.1080/13573322.2014.987745

Orlanda, M. M. (2015). Revisiting the Service Physical Education Program at the Tertiary Level: Basis for A Revitalized Program. Journal of Multidisciplinary Research, 3(5), 29-35.

Pill, S. (2016). Exploring Challenges In Australian Physical Historical Ontology - A Common. Journal of Physical Education \& Health, 5(7), 5-17. 
Rachman, H. A. (2004). Pendidikan Jasmani yang Tepat Merupakan Conditio Sine Qua Non dalam Upaya Membentuk Manusia Indonesia Seutuhnya. Jurnal Pendidikan Jasmani Indonesia, 1(1), 54-61.

Rachman, H. A. (2011). Keterlaksanaan Pendidikan Jasmani dan Olahraga di Daerah Istimewa Yogyakarta. Jurnal Pendidikan Jasmani Indonesia, 8(1), 38-47.

Rohmawati, A. (2015). Efektivitas Pembelajaran. Jurnal Pendidikan Usia Dini, 9(1), 15-32.

Ryan, T., \& Poirier, Y. (2012). Secondary Physical Education Avoidance and Gender: Problems and Antidotes. International Journal of Instruction, 5(2), 173-194.

Samkange, W. (2012). Assessment in education: A Case for Quality and Standards within the Context of Open and Distance Education: A Case Study of One Zimbabwean University. Turkish Online Journal of Distance Education, 13(3), $275-296$. https://doi.org/10.1017/S0967199401001149

Sulistiono, A. A. (2014). Kebugaran Jasmani Siswa Pendidikan Dasar dan Menengah di Jawa Barat. Jurnal Pendidikan dan Kebudayaan, 20(2), 223-233. https://doi.org/10.24832/jpnk.v20i2.140

Suryapermana, N. (2017). Manajemen Perencanaan Pembelajaran. Tarbawi, 3(02), 183-193.

Suyatmini. (2017). Implementasi Kurikulum 2013 pada Pelaksanaan Pembelajaran Akuntansi di Sekolah Menengah Kejuruan. Jurnal Pendidikan Ilmu Sosial, 27(1), 60-68.

Tiessen, R. (2018). Improving Student Reflection in Experiential Learning Reports in Post-Secondary Institutions. Journal of Education and Learning, 7(3), 1-10. https://doi.org/10.5539/jel.v7n3p1

Ugeltha, S., \& Meyvilliano, A. (2017). Character Building Mahasiswa melalui MKU. Jurnal Terapan Ilmu Keolahragaan, $02(01), 1-6$.

Wagner, D., Babson, A., \& Murray, K. (2011). Evaluation, Assessment, and Testing. Current Issues In Comparative Education, 14(1). Retrieved from http://www.tc.columbia.edu/CICE/Issues/14.01/PDFs/14_01_Complete_Issue.pdf

Wang, R. (2017). Research on the reform of physical education and training mode in universities based on information technology. Journal of Mathematics Science and Technology Education, 55(14), 266-273. https://doi.org/10.12973/ejmste/78730

Warsito., \& Kartowagiran, B. (2013). Jurnal Evaluasi Pendidikan. Jurnal Evaluasi Pendidikan, 1(2), $196-207$. 